\title{
Designing and Validating a Scale Measuring Cultural Capitals of Iranian University Students Majoring in English
}

\author{
Ebrahim Khodadady \\ Ferdowsi University of Mashhad, Iran \\ Email: ekhodadady@gmail.com \\ Mottahareh Natanzi \\ Ferdowsi University of Mashhad, Iran
}

\begin{abstract}
This study aimed to design and validate a Persian cultural capital scale (CCS) with Iranian university students majoring in English language, literature and translation as well teaching English as a foreign language. To this end, twenty more cultural capital indicators specified by researchers were added to eleven compiled by Khodadady and Zabihi (2011) and administered to 381 English students of five universities in Mashhad, Iran. When the data were submitted to Principal Axis Factoring and rotated via Varimax with Kaiser Normalization eight rotated factors whose Eigenvalues were one or higher were extracted, i.e., Cultured Family, Cultural Commitment, Cultural Investment, Religious Commitment, Cultural Visits, Literary and Art Studies, Art Appreciation, and Literate Family, indicating that cultural capital is not a unitary construct. The reliability and correlation analysis of the CCS and its underlying factors showed that they enjoy acceptable levels of reliability and correlate significantly with each other. The results are discussed and suggestions are made for future research.
\end{abstract}

Index Terms — cultural capital, factors, validity, English language

\section{INTRODUCTION}

Ever since Bourdieu $(1977,1984,1986)$ brought up the concept of cultural capital (CC) in sociology, a great number of research projects have been conducted to find out how it relates to education. More important than the concept was the provision of a number of indicators through which the relationship could be explored, e.g., museum visits, reading habits, theater attendance and classical music appreciation.

While some authors such as Farkas et al (1990) interpreted CC in terms of informal academic standards, e.g., as homework completion and good citizenship, rewarded by teachers, others tried to find more culture-based indicators. Dika and Singh (2002) and Lareau and

Weininger (2003), reviewed the literature and provided a relatively comprehensive list of these indicators. Based on their most frequently cited indicators, Khodadady and Zabihi (2011) [henceforth K\&Z developed a 35-item questionnaire which dealt not only with the $\mathrm{CC}$ but also with social capital (SC). The CC section of the questionnaire consisted of 11 items whereas the SC section contained 24.

K\&Z administered their 35-indicator social and cultural capital questionnaire (SCCQ) to 173 (43\%) undergraduate students majoring in Persian language and literature and 230 (57\%) undergraduate and graduate students majoring in English language and literature at Ferdowsi University of Mashhad and Mashhad Azad University. They hypothesized that all the items would load on two factors representing to the logically established SC and CC factors. Contrary to their expectations, however, 32 indicators loaded on ten factors, i.e., literacy, parental consultation, family-school interaction, family support, extracurricular activities, family relationship, parent-school encouragement and facility, cultural activities, peer interaction and religious activities.

Among the three indicators which did not load acceptably, i.e., .30 and higher, on any factor, two were cultural, i.e., i.e., I enjoy listening to classical music, and I am a cultured person and one was social, i.e., I see my grandparents weekly, in nature. From among the remaining nine CC indicators, four loaded on the first factor called Literacy by K\&Z, i.e., I enjoy reading (in general), I frequently borrow/buy books, I know a lot about literature, and I enjoy reading literature. Four other indicators loaded on the eighth factor called Cultural Activities, i.e., I know all famous music composers, I frequently visit museums and theaters, I used to take art or music classes outside school, and I know a lot about literature.

K\&Z's extraction of two factors from eight cultural indicators thus showed that CC is not a unitary concept and could possibly have other underlying factors if it was administered in a different context or more indicators were included in an expanded CC scale. Although the literature on 21-item religious orientation scale (ROS), for example, followed Allport and Ross (1967) and adopted a two dimensional view, i.e., intrinsic and extrinsic, Khodadady and Golparvar 
(2011) showed that it embodies four within an Islamic context. Similarly, when Khodadady and Bagheri (2012) added 12 religious indicators to the ROS and administered it to 536 undergraduate students, they extracted seven factors, i.e., Inspirational, Intrinsic, Social, Concessional, Theo-pacific, Humanitarian and Sacrificial.

The present study was, therefore, designed to expand the CC section of K\&Z's SCCQ into a single and comprehensive CCS by including as many CC indicators as possible. It was also decided that the expanded CCS be administered to students of a specific and controlled field, i.e., English language, literature and translation in order to homogenize the sample. This practice is based on the findings of Khodadady, Alaee and Natanzi (2011) [henceforth KA\&N] who administered the K\&Z's SCCQ to seven hundred and six female high school learners studying at grade 1 , 2 and 3 in Mashhad, Iran.

Table 1 presents the factors which were extracted from the CC indicators by K\&Z and KA\&N. As can be seen, the very educational level of sample to which the CC section was administered has affected not only the number of indicators loading acceptably on the extracted and rotated factors but also the percentage of variances they explain in the SCCQ. While the Literacy factor extracted by K\&Z consist, for example, of four indicators and explain 6.3 out of $47.7 \%$ of variance, only two indicators of this factor load on Literary and Artistic Appreciation extracted by KA\&N and together with another indicator explain 4.1 out of $40.1 \%$, in the SCCQ. These results inspired the present researchers to develop a single and comprehensive CCS and administer it to a specific sample whose field is controlled.

TABLE 1.

FACTORS EXTRACTED FROM CC INDICATORS BY K\&Z AND KA\&N

\begin{tabular}{|l|l|l|l|l|}
\hline Study & Factor name & $\begin{array}{l}\text { Factor } \\
\text { rank }\end{array}$ & Constituting indicators & $\begin{array}{l}\text { Variance } \\
\text { explained }\end{array}$ \\
\hline \multirow{3}{*}{ K\&Z } & Literacy & First & $\begin{array}{l}\text { I enjoy reading (in general). } \\
\text { I frequently borrow/buy books. } \\
\text { I know a lot about literature. } \\
\text { I enjoy reading literature. }\end{array}$ & 6.3 out of $47.7 \%$, \\
\cline { 2 - 5 } & Cultural Activities & Eighth & $\begin{array}{l}\text { I know all famous music composers. } \\
\text { I frequently visit museums and theaters. } \\
\text { I used to take art or music classes outside school. } \\
\text { I know a lot about literature. }\end{array}$ & 4.1 out of $47.7 \%$, \\
\hline \multirow{3}{*}{ KA\&N } & $\begin{array}{l}\text { Literary and Artistic } \\
\text { Appreciation }\end{array}$ & Fifth & $\begin{array}{l}\text { I know a lot about literature. } \\
\text { I enjoy reading literature. } \\
\text { I enjoy listening to classical music. }\end{array}$ & 4.1 out of $40.1 \%$, \\
\cline { 2 - 5 } & Reading Enjoyment & Eighth & $\begin{array}{l}\text { I enjoy reading (in general). } \\
\text { I frequently borrow/buy books. }\end{array}$ & 3.2 out of $40.1 \%$, \\
\hline
\end{tabular}

\section{MEthodology}

\section{A. Participants}

Three hundred eighty one, 245 female $(64.3 \%)$ and 136 male (35.7\%), undergraduate university students took part in this study voluntarily. One hundred seventy three (45.4\%), 60 (15.7\%), $52(13.6 \%)$ and $96(24.5 \%)$ were freshmen, sophomore, junior and senior university students, respectively. They were majoring in English Language and Literature $(\mathrm{n}=136,35.7 \%)$, Teaching English as a foreign Language $(\mathrm{n}=165,43.3 \%)$, and Translation $(\mathrm{n}=80,21.0 \%)$ at Ferdowsi University of Mashhad, Imam Reza, Khayyam University, Mashhad Azad and Tabaran universities. Their age ranged between 18 and $41($ Mean $=22.56, \mathrm{SD}=3.56)$ and spoke Persian as their mother language.

\section{B. Instruments}

Two instruments were developed and used in this study, i.e., a bio questionnaire and cultural capital scale.

Bio Questionnaire

Six open-ended questions dealing with the participants' age, mother language, sex, field, year and place of study comprised the bio questionnaire. The marital status and the educational background of the participants' fathers and mothers were also raised in the questionnaire. However, due to their irrelevance to the present study they were not reported. (The relationship of these variables with the CCS and its factors will be explored in a separate paper.)

Cultural Capital Scale

The Persian cultural capital scale (CCS) designed in this study consists of 31 indicators presented as statements dealing with certain cultural tendencies and behaviors of participants. Statement one, i.e., I like to listen to music, for example, is considered as a cultural indicator by scholars such as Borocz (1986), Noble and Davies (2009), Robinson and Garnier (1985) and Sullivan (2001). The participants were required to indicate whether they always, usually, often, seldom or never exhibited the 31 indicators in their everyday life. The values of 5, 3, 2, and 1 were then assigned to these five points to quantify the elicited responses, respectively.

In addition to music, the CCS deals with interest in theatre and television (e.g., Davies, Ganzeboom, DeGraaf \& Robert, 1990; Katsillis \& Rubinson, 1990), going to museum (e.g., Dimaggio, 1982; Fyfe, 2004), going to art galleries and taking art courses (e.g., DiMaggio \& Mukhtar, 2004), cultural trips (e.g., Roscigno \& Ainsworth-Darnell, 1999), self-image (e.g., DiMaggio,1982), general information (e.g., Reay, 1998), sports (e.g., Stempel, 2005), parents (e.g., 
Kalmijn \& Kraaykamp 2009), higher education (e.g., DeGraf \& Kraaykamp, 2000; Brook, 2008; Lareau \& Weininger, 2003; Williams \& Dawson, 2011), religion (e.g., Gamoran \& Boxer, 2005), books (Aschaffenburg \& Maas, 1997), selfexpression (e.g., Blackledg, 2001, Carter, 2003, Heritage,1993) and literary studies (e.g., Robinson \& Garnier, 1985).

\section{Procedures}

Upon developing and having the questionnaires printed and copied, the instructors offering various fields related to the English language were contacted in five private and state universities and their cooperation was sought. Some instructors allowed the researchers to distribute the questionnaires in a single session in their presence after they secured the verbal agreement of their students to fill them out voluntarily. The researchers thus administered the two instruments in person in 2011 and encouraged the participants to raise whatever questions they had. Since both the bio questionnaire and CCS were in Persian and the indicators of the CCS had been revised several times, no particular questions were brought up by the participants.

\section{Data Analysis}

For estimating the reliability of the CCS, Cronbach's Alpha was employed. Along with reliability analysis, Principal Axis Factoring (PAF) was employed to extract the latent variables underlying the CCS. The factors were then rotated via Varimax with Kaiser Normalization so that a clear picture of their loadings could be obtained. The highest loading of any indicator which loaded acceptably on more than one factor was kept as its main contribution to the construct under investigation and its other acceptable loadings were removed from both reliability and correlation analysis. All the statistical tests were run via IBM SPSS Statistics 19.0 to answer the following three hypotheses.

H1. The CCS will be a reliable measure of cultural capitals.

$\mathrm{H} 2$. The factors underlying the CCS will be reliable.

$\mathrm{H} 3$. The factors underlying the CCS will correlate significantly with each other.

\section{RESULTS AND DISCUSSION}

Table 2 presents the descriptive statistics of the CCS. As can be seen, the alpha reliability coefficient obtained for the CCS is 0.87 , confirming the first hypothesis that the CCS will be a reliable measure of cultural capital. If the coefficient of .60 is considered acceptable (e.g., Landau \& Everitt, 2004) then the CCS is a highly reliable measure of social capital. It is also noticeably higher than the coefficient obtained on the 11-item CCS subscale developed by KA\&N, i.e., .73, indicating that the CCS developed in this study is more comprehensive and reliable than the K\&Z's. (The descriptive statistics of indicators comprising the CCS are given in Appendix A).

TABLE 2.

THE DESCRIPTIVE STATISTICS AND RELIABILITY COEFFICIENTS OF CCS

\begin{tabular}{|l|l|l|l|l|l|}
\hline CCS & N & \# of items & Mean & SD & Alpha \\
\hline Present study & 381 & 31 & 95.85 & 17.595 & .87 \\
\hline K\&Z & 403 & 11 & 42.24 & 7.458 & .76 \\
\hline KA\&N & 696 & 11 & 40.77 & 9.456 & .73 \\
\hline
\end{tabular}

Upon establishing the reliability of the answers given to the CCS, the Kaiser-Meyer-Olkin (KMO) measure of Sampling Adequacy was applied to the data and the KMO statistic of .83 was obtained showing that the sample selected in the study was "meritorious" (DiLalla \& Dollinger 2006, p. 250) and the factor analysis employed would probably provide the best common factors. The significant Bartlett's Test of Sphericity, i.e., $\mathrm{X}^{2}=4016.835, \mathrm{df}=465, p<.001$, indicated that the correlation matrix was not an identity matrix.

Table 3 presents the initial and extracted communalities obtained from the $31 \mathrm{CC}$ indicators. As can be seen, the extraction communalities range from .76 (Item 10) to .18 (Items 6 and 26). Although Costello and Osborne (2005) suggested communalities in the order of .40 to .70 in social sciences be considered acceptable, this study suggests the communalities of whatever items loading acceptably on a factor be accepted. As will be shown shortly, since they have lowest extraction communalities items 6 and 26 do not load on any factors extracted in this study.

TABLE 3.

INITIAL AND EXTRACTED COMMUNALITIES OBTAINED VIA PAF

\begin{tabular}{|l|l|l|l|l|l|l|l|l|}
\hline Item & Initial & Extraction & Item & Initial & Extraction & Item & Initial & Extraction \\
\hline $\mathrm{I} 1$ & .339 & .390 & $\mathrm{I} 12$ & .471 & .538 & $\mathrm{I} 23$ & .309 & .327 \\
\hline $\mathrm{I} 2$ & .369 & .564 & $\mathrm{I} 13$ & .474 & .493 & $\mathrm{I} 24$ & .263 & .227 \\
\hline $\mathrm{I} 3$ & .337 & .354 & $\mathrm{I} 14$ & .489 & .568 & $\mathrm{I} 25$ & .461 & .544 \\
\hline $\mathrm{I} 4$ & .464 & .537 & $\mathrm{I} 15$ & .493 & .526 & $\mathrm{I} 26$ & .248 & .184 \\
\hline $\mathrm{I} 5$ & .501 & .748 & $\mathrm{I} 16$ & .424 & .496 & $\mathrm{I} 27$ & .394 & .509 \\
\hline $\mathrm{I} 6$ & .200 & .180 & $\mathrm{I} 17$ & .351 & .369 & $\mathrm{I} 28$ & .253 & .298 \\
\hline $\mathrm{I} 7$ & .334 & .301 & $\mathrm{I} 18$ & .566 & .588 & $\mathrm{I} 29$ & .388 & .411 \\
\hline $\mathrm{I} 8$ & .506 & .550 & $\mathrm{I} 19$ & .608 & .699 & $\mathrm{I} 30$ & .603 & .655 \\
\hline $\mathrm{I} 9$ & .507 & .512 & $\mathrm{I} 20$ & .431 & .491 & $\mathrm{I} 31$ & .524 & \\
\hline $\mathrm{I} 10$ & .622 & .764 & $\mathrm{I} 21$ & .380 & .408 & & & \\
\hline $\mathrm{I} 11$ & .370 & .451 & $\mathrm{I} 22$ & .315 & .291 & & & \\
\hline
\end{tabular}


Table 4 presents the eight rotated factors extracted via the PAF, Varimax with Kaiser Normalization. As can be seen, eight items loaded acceptably, i.e., .30 and higher, on more than one factor, i.e., 1, 3, 7, 16, 21, 27, 30 and 31. The highest loading of these indicators on a given factor was considered as its main contribution to the construct under investigation and its lower cross loadings on other factors were removed. For example, indicator one, I like to listen to music, loaded -.32 on factor 4 but had a higher and positive loading on factor 7, i.e., .51. Based on the arbitrarily adopted rule, the first negative and lower cross loading was, therefore, removed in the reliability and correlational analyses of factor four.

TABLE 4.

ROTATED FACTORS EXTRACTED FROM THE CCS

\begin{tabular}{|c|c|c|c|c|c|c|c|c|c|c|c|c|c|c|c|c|c|}
\hline Item & 1 & 2 & 3 & 4 & 5 & 6 & 7 & 8 & Item & 1 & 2 & 3 & 4 & 5 & 6 & 7 & 8 \\
\hline I1 & $*$ & $*$ & $*$ & -.32 & $*$ & $*$ & .51 & $*$ & I17 & .54 & $*$ & $*$ & $*$ & $*$ & $*$ & * & $*$ \\
\hline I2 & * & * & $*$ & $*$ & $*$ & $*$ & .71 & $*$ & I18 & .74 & $*$ & $*$ & $*$ & $*$ & * & * & $*$ \\
\hline I3 & $*$ & $*$ & $*$ & $*$ & .35 & $*$ & .38 & $*$ & I19 & .78 & $*$ & * & $*$ & $*$ & * & * & $*$ \\
\hline I4 & $*$ & $*$ & $*$ & $*$ & 68 & $*$ & $*$ & $*$ & I 20 & .60 & $*$ & * & $*$ & $*$ & $*$ & $*$ & $*$ \\
\hline I5 & $*$ & * & $*$ & $*$ & .83 & $*$ & $*$ & $*$ & I 21 & .35 & .50 & * & $*$ & $*$ & $*$ & * & $*$ \\
\hline I6 & * & * & $*$ & $*$ & $*$ & $*$ & $*$ & $*$ & I22 & $*$ & .46 & $*$ & $*$ & $*$ & $*$ & $*$ & $*$ \\
\hline I7 & $*$ & $*$ & .39 & $*$ & $*$ & .33 & $*$ & $*$ & I23 & $*$ & .52 & $*$ & $*$ & $*$ & $*$ & $*$ & $*$ \\
\hline I8 & $*$ & * & \begin{tabular}{|c|}
.68 \\
\end{tabular} & $*$ & $*$ & $*$ & $*$ & $*$ & I24 & 30 & $*$ & $*$ & $*$ & $*$ & * & $*$ & $*$ \\
\hline \begin{tabular}{|l|}
19 \\
\end{tabular} & $*$ & & 69 & $*$ & $*$ & $*$ & $*$ & $*$ & I 25 & $*$ & $*$ & $*$ & .66 & $*$ & $*$ & $*$ & $*$ \\
\hline I10 & $*$ & & .85 & $*$ & $*$ & $*$ & $*$ & $*$ & I26 & $*$ & $*$ & $*$ & $*$ & $*$ & $*$ & $*$ & $*$ \\
\hline \begin{tabular}{|l|l|} 
I11 \\
\end{tabular} & $*$ & .60 & $*$ & $*$ & $*$ & $*$ & $*$ & $*$ & I 27 & .32 & $*$ & $*$ & $*$ & $*$ & $*$ & $*$ & .59 \\
\hline \begin{tabular}{|l|}
$\mathrm{I} 12$ \\
\end{tabular} & $*$ & .63 & $*$ & $*$ & $*$ & $*$ & $*$ & $*$ & I 28 & $*$ & $*$ & $*$ & $*$ & $*$ & $*$ & $*$ & .50 \\
\hline I13 & $*$ & .56 & $*$ & $*$ & $*$ & $*$ & $*$ & $*$ & I 29 & $*$ & $*$ & $*$ & $*$ & $*$ & .49 & * & $*$ \\
\hline I14 & $*$ & $*$ & $*$ & .70 & $*$ & $*$ & $*$ & $*$ & I 30 & $*$ & $*$ & $*$ & $*$ & .40 & .54 & $*$ & $*$ \\
\hline I15 & $*$ & * & $*$ & .67 & $*$ & $*$ & $*$ & $*$ & I31 & $*$ & $*$ & $*$ & $*$ & $*$ & .45 & * & .35 \\
\hline II6 & .39 & $*$ & $*$ & .58 & $*$ & $*$ & $*$ & $*$ & & & & & & & & & \\
\hline
\end{tabular}

As it can also be seen in Table 4, neither indicator 6, I prefer to eat in traditional eateries than in fast food restaurant, nor 26, I solve cross-word puzzles in my free time, load on any factor. These two items have the lowest extraction communalities and do no bear on latent variables underlying the CC in Mashhad, Iran. Since these two indicators did not load on any factor, the reliability of the CCS was calculated two times. As shown in Table 5, the alpha reliability coefficient (RC) of the CCS decreases very slightly to .86 when indicators 6 and 26 are removed from analysis.

Table 5 presents the descriptive statistics of the eight rotated factors underlying the CCS. As can be seen, the alpha RCs range from .49 to .76, confirming the second hypothesis that the factors underlying the CCS will be reliable. While factors two and three have the highest RC, i.e., $\alpha=.76$, factor one has the lowest, $\alpha=.49$. The low RC of this factor can, however, be considered acceptable because Khodadady (2009) obtained .57 on the 34-item Beliefs about Language Learning Inventory (BALLI) when he administered it to 418 university students. Following Khodadady it is argued that the heterogeneous nature of items constituting factor one has contributed to its relatively low RC.

TABLE 5.

DESCRIPTIVE STATISTICS AND RELIABILITY COEFFICIENTS OF FACTORS UNDERLYING THE CCS

\begin{tabular}{|c|c|c|c|c|c|c|}
\hline Factor & No of items & Items & Mean & Std. Deviation & $\begin{array}{l}\text { \% of Variance } \\
\text { explained }\end{array}$ & Alpha \\
\hline 1 & 5 & $17,18,19,20,24$ & 21.69 & 4.712 & 8.208 & .490 \\
\hline 2 & 6 & $11,12,13,21,22,23$ & 17.72 & 5.346 & 7.422 & .759 \\
\hline 4 & 4 & $14,15,16,25$ & 9.54 & 3.761 & 6.967 & .626 \\
\hline 5 & 2 & 4,5 & 5.69 & 2.149 & 5.692 & .768 \\
\hline 6 & 3 & $29,30,31$ & 9.20 & 3.246 & 3.989 & .756 \\
\hline 8 & 2 & 27,28 & 5.26 & 2.091 & 3.517 & .605 \\
\hline $\mathrm{CCS}$ & 29 & & 90.40 & 16.707 & 46.873 & .86 \\
\hline $\mathrm{CCS}$ & 31 & & 95.85 & 17.595 & - & .87 \\
\hline
\end{tabular}

Table 6 presents the correlation coefficients (CCs) obtained among the factors comprising the CCS. As can be seen, with the exception of factor 3 which does not correlate significantly with Factor 1 only, the other seven factors do correlate significantly with each other and thus confirm the third hypothesis that the factors underlying the CCS will correlate significantly with each other. Factor 7 correlates significantly and positively with the other factors, it does, however, show negative but significant relationship with factor 4 . These correlations will be discussed shortly. 
TABLE 6.

CORRELATIONS COEFFICIENTS OBTAINED AMONG THE CCS AND ITS EIGHT FACTORS

\begin{tabular}{|l|l|l|l|l|l|l|l|l|l|l|}
\hline No & CCS \& Factors & $\mathbf{C C}$ & $\mathbf{1}$ & $\mathbf{2}$ & $\mathbf{3}$ & $\mathbf{4}$ & $\mathbf{5}$ & $\mathbf{6}$ & $\mathbf{7}$ & $\mathbf{8}$ \\
\hline & CCS & 1 & $.66^{* *}$ & $.75^{* *}$ & $.58^{* *}$ & $.51^{* *}$ & $.52^{* *}$ & $.73^{* *}$ & $.42^{* *}$ & $.52^{* *}$ \\
\hline 1 & Cultured Family & $.66^{* *}$ & 1 & $.43^{* *}$ & .09 & $.34^{* *}$ & $.12^{* *}$ & $.35^{* *}$ & $.14^{* *}$ & $.55^{* *}$ \\
\hline 2 & Cultural Commitment & $.75^{* *}$ & $.43^{* *}$ & 1 & $.30^{* *}$ & $.26^{* *}$ & $.27^{* *}$ & $.40^{* *}$ & $.24^{* *}$ & $.31^{* *}$ \\
\hline 3 & Cultural Investment & $.58^{* *}$ & .09 & $.30^{* *}$ & 1 & $.16^{* *}$ & $.30^{* *}$ & $.42^{* *}$ & $.22^{* *}$ & $.19^{* *}$ \\
\hline 4 & Religious Commitment & $.51^{* *}$ & $.34^{* *}$ & $.26^{* *}$ & $.16^{* *}$ & 1 & $.24^{* *}$ & $.26^{* *}$ & $-.15^{* *}$ & $.19^{* *}$ \\
\hline 5 & Cultural Visits & $.52^{* *}$ & $.12^{* *}$ & $.27^{* *}$ & $.30^{* *}$ & $.24^{* *}$ & 1 & $.45^{* *}$ & $.30^{* *}$ & $.13^{*}$ \\
\hline 6 & Literary and Art Studies & $.73^{* *}$ & $.35^{* *}$ & $.40^{* *}$ & $.42^{* *}$ & $.26^{* *}$ & $.45^{* *}$ & 1 & $.38^{* *}$ & $.36^{* *}$ \\
\hline 7 & Art Appreciation & $.42^{* *}$ & $.14^{* *}$ & $.24^{* *}$ & $.22^{* *}$ & $-.15^{* *}$ & $.30^{* *}$ & $.38^{* *}$ & 1 \\
\hline 8 & Literate Family & $.52^{* *}$ & $.55^{* *}$ & $.31^{* *}$ & $.19^{* *}$ & $.19^{* *}$ & $.13^{*}$ & $.36^{* *}$ & $.12^{*}$ & 1 \\
\hline
\end{tabular}

As it can also be seen in Table 6, factors 1, 2, 3, 4, 5, 6, 7 and 8 are called Cultured Family, Cultural Commitment, Cultural Investment, Religious Commitment, Cultural Visits, Literary and Art Studies, Art Appreciation, and Literate Family in this study, respectively. The descriptive statements of capitals loading on these factors as well as the two indicators having no acceptable loadings on any factors are given in Appendix B. The number of factors as well as the acceptable loading of each indicator on a single factor are also given in the appendix.)

The first factor, Cultured Family, consists of five indicators, 17, 18, 19, 20 and 24, and out of $46.9 \%$ of variance in the CCS it explains $8.2 \%$. It represents families who communicate well with the members of their society, attend sports classes and like to continue their education at higher levels. These activities and inclinations provide the basis for Mashhadi English students to consider not only their families but also themselves cultured. Cultured Family correlates the highest with the eighth factor, Literate Family, i.e., $\mathrm{r}=.55, p<.01$, and thus explain $30 \%$ of variance in each other.

Six capitals, i.e., 11, 12, 13, 21, 22, and 23, load acceptably on the second factor, Cultural Commitment and explain $7.4 \%$ out of $46.9 \%$ of variance in the CCS. It entails reading scientific magazines and buying newspapers regularly every day as the two highest loading activities, i.e., .63 and .60, respectively. Studying magazine articles dealing with culture, visiting news and political websites, watching documentaries and using internet to accomplish official tasks also contribute to Cultural Commitment. It correlates the highest with the sixth factor, Literary and Art Studies $(\mathrm{r}=.40$, $p<.01)$ and shares $16 \%$ of variance with it.

Four capitals, i.e., 7, 8, 9 and 10, load acceptably on the third factor, Cultural Investment, explaining $7.2 \%$ out of $46.9 \%$ of variance in the CCS. Among the four, indicator 10, I buy lots of books, study and keep them in my library, has the highest loading (.85) on factor 3. Along with purchasing books, factor four requires having a library at home, enriching it with new books, having extracurricular study in leisure time and becoming a member of libraries. Similar to Cultural Commitment, Cultural Investment correlates the highest with Literary and Art Studies $(\mathrm{r}=.42, p<.01)$. However, it shares slightly more variance with factor 6, i.e., $17 \%$.

Among the eight factors, Cultural Investment is the only factor which does not show any significant relationship with Cultured Family, implying that English students who invest in their studies do not necessarily believe that they belong to a cultured family whose main activity is attending sports classes. Nor is Cultural Investment necessarily dependent upon the inclination to strive for higher education. In other words, it stems from a more intrinsic motivation than an external or instrumental one.

The fourth factor, Religious Commitment, comprises the indicators 14, 15, 16 and 25, explaining 6.97\% out of 46.9\% variance in the CCS. It involves listening to religious radio stations, attending commentary classes on the Quran and hadith, i.e., what is reported from the Prophet Mohammad (PBUH), and visiting the shrines of Imams and their offsprings. It correlates the highest with the first factor, Cultured Family $(\mathrm{r}=.34, p<.01)$ and shares $12 \%$ of variance with it.

Religious Commitment is the only factor which relates negatively to the seventh factor, Art Appreciation $(\mathrm{r}=-.15, p$ $<.01$ ), indicating that the more committed English students are to their religion, the less they appreciate art. Although the amount of variance Religious Commitment explains in the Art Appreciation is really small (2\%), it calls for further research exploring whether the factors extracted from CC indicators are influenced by the students' field of study.

The fifth factor, Cultural Visits, comprises two indicators, i.e., 4 and 5, having the acceptable loadings of .68 and .83, respectively, and explaining $5.7 \%$ out of $46.9 \%$ of variance in the CCS. It involves visiting handy-craft galleries as well as museum and historical places. It reveals the same amount of significant relationship with Cultural Investment and Art Appreciation $(\mathrm{r}=.30, p<.01)$, explaining nine percent of variance in each other.

The sixth factor, Art Visits, which comprises indicator 29, 30 and 31, does however, show the highest correlations with Cultural Visits $(\mathrm{r}=.45, p<.01)$. It entails not only visiting art exhibitions and attending art courses but also showing interest in literature and poetry along with having literal studies. While it explains $3.99 \%$ out of $46.9 \%$ of variance in the CCS, it increases to 20 percent of variance in its fifth factor, Cultural Visits, showing how closely arts and culture are related to each other.

Indicators 1, 2 and 3 comprise the seventh factor, Art Appreciation, upon which they load $.51, .71$ and .38, respectively. As a latent variable underlying cultural capital, Art Appreciation accrues as a result of liking to attend art 
courses, liking to listen to music and play a musical instrument and enjoying watching theoretical performances on television. It explains $3.88 \%$ of variance in the CCS and correlates the highest with Art Visits $(\mathrm{r}=.38, p<.01)$.

Indicators 27 and 28 loaded acceptably, i.e., .59 and .50, respectively, on the eighth and last factor, Literate Family, explaining $3.52 \%$ out of $46.9 \%$ of variance in the CCS. The undergraduate university students who are brought up by literate families have parents who study in their leisure time and can communicate in English as a foreign language in Iran. It correlates the highest with the first factor, Cultured Family $(\mathrm{r}=.55, p<.01)$ and shares $30 \%$ of variance with it.

\section{CONCLUSION}

The 11-item cultural capital section of the composite questionnaire developed on both cultural and social capitals by $\mathrm{K} \& \mathrm{Z}$ was expanded into a single scale in the present study by modifying them and adding 20 more indicators identified by a number of researchers. The single 31-item cultural capital scale (CCS) was then administered to 381 undergraduate university students majoring in English language and literature, teaching English as a foreign language and English translation in five universities in Mashhad, Iran, in 2011. When the Principal Axis Factoring was applied to the answers collected and latest variables having Eigenvalues of one and higher were rotated via Varimax with Kaiser Normalization, eight factors appeared, i.e., Cultured Family, Cultural Commitment, Cultural Investment, Religious Commitment, Cultural Visits, Literary and Art Studies, Art Appreciation, and Literate Family.

The results of this study show that not only the CCS itself but also its eight factors are reliable. Furthermore, the majority of factors not only correlate significantly with the CCS but also with each other. As the first factor explaining the highest variance in the CCS, Cultured Family does not, however, show any significant relationship with Cultural Investment, calling for further research to find out why Mashhadi students do not relate their being cultured to cultural investment as materialized by self declaration of having a library at home and buying and studying books at leisure time.

Out of eight factors, six correlated significantly and positively with each other. Religious Commitment, however, was the only factor which showed significant but negative correlation with Art Appreciation, indicating that the more religiously committed the English students are, the less they listen to music, attend art courses, play musical instruments and enjoy watching theoretical performances on television. Future research must show whether the CCS developed in this study reveal any significant relationships with abilities such as English language achievement and proficiency and whether gender and family education play any significant role in the relationships.

APPENDIX A

THE DESCRIPTIVE STATISTICS OF ITEMS COMPRISING THE CCS ( $\mathrm{N}=381$ )

\begin{tabular}{|c|c|c|c|c|c|c|c|c|}
\hline Item & Mean & SD & $\begin{array}{l}\text { Missing } \\
\%\end{array}$ & $\begin{array}{l}\text { Never } \\
\% \\
\end{array}$ & $\begin{array}{l}\text { Seldom } \\
\%\end{array}$ & $\begin{array}{l}\text { Sometimes } \\
\%\end{array}$ & $\begin{array}{l}\text { Often } \\
\% \\
\end{array}$ & \begin{tabular}{|l} 
Always \\
$\%$
\end{tabular} \\
\hline I1 & 4.4 & 0.804 & 0 & 0 & 3 & 12 & 27 & 58 \\
\hline $\mathrm{I} 2$ & 3.47 & 1.437 & 1 & 12 & 17 & 17 & 18 & 35 \\
\hline $\mathrm{I3}$ & 2.59 & 1.32 & 1 & 24 & 25 & 26 & 13 & 11 \\
\hline $\mathrm{I} 4$ & 2.92 & 1.166 & 0 & 10 & 29 & 30 & 19 & 12 \\
\hline I5 & 2.77 & 1.219 & 1 & 15 & 27 & 29 & 19 & 9 \\
\hline I6 & 3.08 & 1.236 & 1 & 10 & 20 & 28 & 27 & 13 \\
\hline I7 & 3.1 & 1.352 & 1 & 13 & 23 & 23 & 21 & 20 \\
\hline I8 & 3.35 & 1.148 & 1 & 5 & 17 & 33 & 26 & 19 \\
\hline I9 & 3.31 & 1.569 & 1 & 18 & 17 & 10 & 20 & 34 \\
\hline $\mathrm{I10}$ & 2.97 & 1.329 & 1 & 14 & 26 & 21 & 22 & 16 \\
\hline I11 & 2.5 & 1.357 & 2 & 28 & 23 & 20 & 17 & 9 \\
\hline I12 & 2.84 & 1.202 & 3 & 10 & 26 & 32 & 20 & 9 \\
\hline I13 & 2.9 & 1.271 & 3 & 11 & 21 & 35 & 18 & 13 \\
\hline I14 & 2.01 & 1.189 & 3 & 40 & 27 & 17 & 9 & 4 \\
\hline I15 & 1.9 & 1.121 & 2 & 45 & 27 & 15 & 8 & 3 \\
\hline I16 & 3.01 & 1.213 & 3 & 10 & 17 & 36 & 24 & 11 \\
\hline I17 & 3.76 & 1.166 & 3 & 2 & 7 & 21 & 39 & 29 \\
\hline I18 & 4.11 & 1.17 & 4 & 1 & 2 & 10 & 37 & 45 \\
\hline I19 & 4.27 & 1.113 & 3 & 1 & 2 & 9 & 29 & 55 \\
\hline $\mathrm{I} 20$ & 4.39 & 1.201 & 3 & 2 & 5 & 6 & 13 & 71 \\
\hline I21 & 3.78 & 1.283 & 3 & 4 & 9 & 17 & 30 & 37 \\
\hline $\mathrm{I} 22$ & 3 & 1.396 & 3 & 16 & 18 & 22 & 25 & 16 \\
\hline I23 & 2.71 & 1.395 & 2 & 22 & 21 & 24 & 17 & 14 \\
\hline I24 & 3.26 & 1.366 & 4 & 7 & 15 & 30 & 20 & 23 \\
\hline $\mathrm{I} 25$ & 2.63 & 1.305 & 2 & 19 & 29 & 23 & 16 & 10 \\
\hline I26 & 2.37 & 1.354 & 3 & 30 & 26 & 19 & 12 & 10 \\
\hline I27 & 3.36 & 1.31 & 3 & 7 & 12 & 29 & 26 & 23 \\
\hline I28 & 1.9 & 1.155 & 2 & 45 & 28 & 14 & 6 & 4 \\
\hline I29 & 3.35 & 1.411 & 2 & 10 & 16 & 22 & 22 & 28 \\
\hline $\mathrm{I} 30$ & 3.03 & 1.242 & 3 & 9 & 19 & 32 & 24 & 13 \\
\hline I31 & 2.82 & 1.3 & 2 & 15 & 25 & 26 & 21 & 11 \\
\hline
\end{tabular}


APPENDIX B

INDICATORS COMPRISING THE CCS AND THE FACTOR UPON WHICH THEY LOAD

\begin{tabular}{|c|c|c|c|}
\hline No & Capital & Factor & Loading \\
\hline 1 & I like to listen to music. & 7 & 0.51 \\
\hline 2 & I like to attend art courses and play an instrument. & 7 & 0.71 \\
\hline 3 & I enjoy watching theatres on TV. & 7 & 0.38 \\
\hline 4 & I visit museum and historical places. & 5 & 0.68 \\
\hline 5 & I visit handy-craft galleries. & 5 & 0.83 \\
\hline 6 & I prefer to eat in traditional eateries than in fast food restaurant. & & \\
\hline 7 & I have library membership & 3 & 0.39 \\
\hline 8 & I have extracurricular study in my leisure time & 3 & 0.68 \\
\hline 9 & I have personal library in my room and add new books to that. & 3 & 0.69 \\
\hline 10 & I buy lots of books, study and keep them in my library. & 3 & 0.85 \\
\hline 11 & I buy newspapers regularly every day. & 2 & 0.60 \\
\hline 12 & I read scientific magazines. & 2 & 0.63 \\
\hline 13 & I study cultural part of the magazines & 2 & 0.56 \\
\hline 14 & I listen to religious radio stations & 4 & 0.70 \\
\hline 15 & I attend commentary classes on the Quran and Hadith & 4 & 0.67 \\
\hline 16 & I visit the holy shrine of Imam Reza regularly. & 4 & 0.58 \\
\hline 17 & I have fluency in my speech and others understand me easily & 1 & 0.54 \\
\hline 18 & I am a cultured person & 1 & 0.74 \\
\hline 19 & I have grown up in a cultured family & 1 & 0.78 \\
\hline 20 & I like to continue my education to higher level & 1 & 0.60 \\
\hline 21 & I watch documentaries on TV & 2 & 0.50 \\
\hline 22 & I use internet for doing my different official works. & 2 & 0.46 \\
\hline 23 & I visit news and political websites & 2 & 0.52 \\
\hline 24 & I attend sport classes & 1 & 0.30 \\
\hline 25 & While traveling, I prefer to visit shrines of Imam's offspring & 4 & 0.66 \\
\hline 26 & I solve cross-word puzzles in my free time & & \\
\hline 27 & My parents study in their leisure time & 8 & 0.59 \\
\hline 28 & My parents can communicate in English & 8 & 0.50 \\
\hline 29 & I am interested in literature and poetry and have literal study & 6 & 0.49 \\
\hline 30 & I visit art exhibitions & 6 & 0.54 \\
\hline 31 & I attend art courses. & 6 & 0.45 \\
\hline
\end{tabular}

\section{REFERENCES}

[1] Allport, G. W., \& Ross, J. M. (1967). Personal religious orientation and prejudice. Journal of Personality and Social Psychology, 5, 447-457.

[2] Aschaffenburg, K., \& Maas, I. (1997). Cultural and Educational Careers: The Dynamics of Social Reproduction. American Sociological Review, 62, 573-587.

[3] Blackledge, A. (2001). The wrong sort of capital. International Journal of Bilingualism, 5(3), 345-369.

[4] Borocz, J. (1986). Decomposing the intellectual's class power: Conversations of cultural capital to income, Hungary. Social Force, 74(3), 797-821.

[5] Bourdieu, P. (1977). Cultural Reproduction and Social Reproduction. In J. Karabel \& A.H. Halsey. (eds.). Power and Ideology in Education (487-511). New York: Oxford University Press.

[6] Bourdieu, P. (1984). Distinction: A Social Critique of the Judgment of Taste. Cambridge: Harvard University Press.

[7] Bourdieu, P. (1986). The forms of capital. In J. Richardson (Ed.), Handbook of theory and research for the sociology of education (pp. 241-258). Westport, CT: Green-wood Press.

[8] Brook, R. (2008). Accessing higher education: The influence of cultural and social capital on university choice. Sociology Compass, 2(4), 1355-1371.

[9] Carter, P. L. (2003). "Black" cultural capital, status positioning, and schooling conflicts for low-income African American youth. Social Problems, 50(1), 136-155.

[10] De Graaf, P. M., De Graaf, \& Kraaykaamp, G. (2000). Parental cultural capital and educational attainment in the Netherlands: A refinement of the cultural capital perspective. Sociology of Education, 73, 92-111.

[11] Dika, S. L., Singh, K. (2002). Applications of Social Capital in Educational Literature: A Critical Synthesis. Review of Educational Research, 72 (1), 31-60.

[12] DiLalla, D. L., \& Dollinger, S. J. (2006). Cleaning up data and running preliminary analyses. In F. T. L. Leong and J. T. Austin (Ed.). The psychology research handbook: A guide for graduate students and research assistants (241-253). California: Sage.

[13] DiMaggio, P. (1982). Cultural capital and school success: The impact of status culture participation on the grades of U.S. high school students. American Sociological Review 47, 189-201.

[14] DiMaggio, P., \& Mukhtar, T. (2004). Arts participation as cultural capital in the United States, 1982-2002: Signs of decline? Poetics 32, 169-194.

[15] Farkas, G., Grobe, R., Sheehan, D., \& Shuan, Y. (1990). Cultural resources and school success: gender, ethnicity, and poverty groups within an urban district. American Sociological Review, 55, 127-142.

[16] Fyfe, G. (2004). Reproductions, cultural capital and museums: Aspects of the culture of copies. Museum And Society, 2(1), 4767. 
[17] Gamoran, A., \& Boxer, M. (2005). Religious participation as cultural capital development: Sector differences in Chicago's Jewish schools. Catholic Education: A Journal of Inquiry and Practice, 8(4), 440-462.

[18] Ganzeboom, H. B. G., De Graaf, P., \& Robert, P. (1990). Cultural reproduction: Theory on socialist ground. Research in Social Stratification and Mobility, 9, 79-104.

[19] Heritage, J. (1993), Linguistic Anthropology: Language and Symbolic Power. Pierre Bourdieu (John B. Thompson, ed.; Gino Raymond and Matthew Adamson, trans.). American Anthropologist, 95, 213-214. doi: 10.1525/aa.1993.95.1.02a00690

[20] Kalmijn, M., \& Kraaykaamp, G. (1996). Race, cultural capital, and schooling: An analysis of trends in the United States. Sociology of Education, 69, 22-34.

[21] Kastillis, J., \& Rubinson, R. (1990). Cultural capital, student achievement and educational reproduction. American Sociological Review, 55, 270-279.

[22] Khodadady, E., \& Bagheri, N. (2012). Construct Validation of a Modified Religious Orientation Scale within an Islamic Context. International Journal of Business and Social Science, 3(11), 237-246.

[23] Khodadady, E., \& Golparvar, E. (2011). Factors underlying religious orientation scale: a methodological approach. Ilahiyat Studies: A Journal on Islamic and Religious Studies, 2(2), 215-235.

[24] Khodadady, E., \& Zabihi, R. (2011). Social and Cultural Capital: Underlying Factors and Their Relationship with the School Achievement of Iranian University Student. International Education Studies, 4(2), 63-71. doi:10.5539/ies.v4n2p63

[25] Khodadady, E., Alaee, F. F., \& Natanzi, M. (2011). Factors underlying the social and cultural capitals of high school students and their relationship with English achievement. Theory and Practice in Language Studies, 1 (11), 1618-1627. doi:10.4304/tpls.1.11.1618-1627.

[26] Landau, S. \& Everitt, B. S. (2004). A handbook of statistical analyses using SPSS. Boca Raton, FL: Chapman \& Hall.

[27] Lareau, A., \& Weininger, E. B. (2003). Cultural capital in educational research: A critical assessment. Theory and Society, 32, 567-606.

[28] Noble, J., \& Davies, P. (2009). Cultural capital as an explanation of variation in participation in higher education. British Journal of Sociology of Education, 30(5), 591-605. DOI:10.1080/01425690903101098.

[29] Reay, D. (1998). Rethinking social class: Qualitative perspectives on gender and social class. Sociology, 32(2), $259-275$.

[30] Robinson, R.V., \& Garnier, M. (1985). Class reproduction among men and women in France. American Journal of Sociology, 91, 250-280.

[31] Roscigno, V., \& Ainsworth-Darnell, J. W. (1999). Race. cultural capital, and educational resources: Persistent inequalities and achievement returns. Sociology of Education, 72, 158-178.

[32] Stempel, C. (2005). Adult Participation Sports as Cultural Capital: A Test of Bourdieu's Theory of the Field of Sports. International Review for the Sociology of Sport, 40(4), 411-432.

[33] Sullivan, A. (2001). Cultural capital and educational attainment. Sociology, 35(4), 893-912.

[34] Williams, S. H. A., \& Dawson, B. A. (2011). The effects of familial capital on the academic achievement of elementary Latino/a students' families in societies. The journal of Contemporary Social Services, 92(1), 91-98.

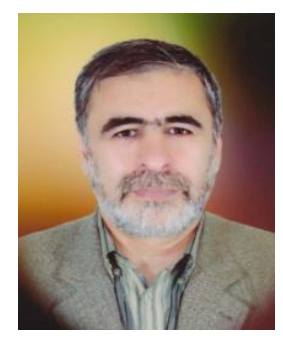

Ebrahim Khodadady was born in Iran in 1958. He obtained his $\mathrm{PhD}$ in Applied Linguistics from the University of Western Australia in 1998. He holds TESL Ontario and Canadian Language Benchmarks Placement Test (CLPBPT) certificates and has taught English as a first, second and foreign language to high school and university students in Australia, Canada and Iran.

$\mathrm{He}$ is currently an academic member of English Language and Literature Department at Ferdowsi University of Mashhad, Iran. He was invited as a VIP by Brock University in Canada in 2004 and served as the Associate Director of Assessment Center at George Brown College in Toronto for almost a year. His published books are Multiple-Choice Items in Testing: Practice and Theory (Tehran, Rahnama, 1999), Reading Media Texts: Iran-America Relations (Sanandaj, Kurdistan University, 1999) and English Language Proficiency Course: First Steps (Sanandaj, Kurdistan University, 2001). His main research interests are Testing, Language Learning and Teaching.

Dr. Khodadady is currently a member of Teaching English Language and Literature Society of Iran (TELLSI), TESL Ontario and European Society for Translation Studies. He is on the editorial board of Ferdowsi Review: An Iranian Journal of TESL, Literature and Translation Studies and has reviewed some research papers for Iranian Journal of Applied Linguistics and TESL Canada Journal as a guest reviewer.

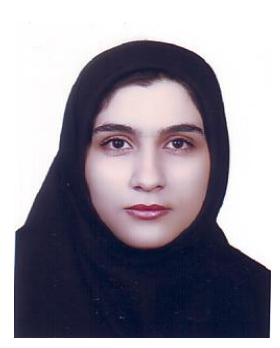

Motahareh Natanzi was born in Iran in 1987. She holds an M. A degree in Teaching English as a Foreign Language and is currently teaching general English at all proficiency levels in different institutes and private schools of Mashhad. 